\title{
Front Matter: Volume 9394
}

, "Front Matter: Volume 9394," Proc. SPIE 9394, Human Vision and Electronic Imaging XX, 939401 (10 April 2015); doi: 10.1117/12.2192629

SPIE Event: SPIE/IS\&T Electronic Imaging, 2015, San Francisco, California, United SPIE. States 


\title{
Human Vision and Electronic Imaging $\mathbf{X X}$
}

\author{
Bemice E. Rogowitz \\ Thrasyvoulos N. Pappas \\ Huib de Ridder \\ Editors
}

\section{9-12 February 2015 \\ San Franc isc 0, Califomia, United States}

Sponsored by

IS\&T-The Society for Imaging Science and Technology

SPIE

Cosponsored by

RTSchool of Media Sciences (United States)

Dolby (United States)

Published by

SPIE 
The papers included in this volume were part of the technical conference cited on the cover and title page. Papers were selected and subject to review by the editors and conference program committee. Some conference presentations may not be available for publication. The papers published in these proceedings reflect the work and thoughts of the authors and are published herein as submitted. The publishers are not responsible for the validity of the information or for any outcomes resulting from reliance thereon.

Please use the following format to cite material from this book:

Author(s), "Title of Paper," in Human Vision and Electronic Imaging XX, edited by Bernice E. Rogowitz, Thrasyvoulos N. Pappas, Huib de Ridder, Proceedings of SPIE-IS\&T Electronic Imaging, SPIE Vol. 9394, Article CID Number (2015)

ISSN: 0277-786X

ISBN: 9781628414844

Copublished by

SPIE

P.O. Box 10, Bellingham, Washington 98227-0010 USA

Telephone +1 3606763290 (Pacific Time) · Fax +1 3606471445

SPIE.org

and

IS\&T-The Society for Imaging Science and Technology

7003 Kilworth Lane, Springfield, Virginia, 22151 USA

Telephone +1 7036429090 (Eastern Time) · Fax +1 7036429094

imaging.org

Copyright (C 2015, Society of Photo-Optical Instrumentation Engineers and The Society for Imaging Science and Technology.

Copying of material in this book for internal or personal use, or for the internal or personal use of specific clients, beyond the fair use provisions granted by the U.S. Copyright Law is authorized by the publishers subject to payment of copying fees. The Transactional Reporting Service base fee for this volume is $\$ 18.00$ per article (or portion thereof), which should be paid directly to the Copyright Clearance Center (CCC), 222 Rosewood Drive, Danvers, MA 01923. Payment may also be made electronically through CCC Online at copyright.com. Other copying for republication, resale, advertising or promotion, or any form of systematic or multiple reproduction of any material in this book is prohibited except with permission in writing from the publisher. The CCC fee code is 0277-786X/15/\$18.00.

Printed in the United States of America.

Paper Numbering: Proceedings of SPIE follow an e-First publication model, with papers published first online and then in print. Papers are published as they are submitted and meet publication criteria. A unique citation identifier (CID) number is assigned to each article at the time of the first publication. Utilization of CIDs allows articles to be fully citable as soon as they are published online, and connects the same identifier to all online, print, and electronic versions of the publication. SPIE uses a six-digit CID article numbering system in which:

- The first four digits correspond to the SPIE volume number.

- The last two digits indicate publication order within the volume using a Base 36 numbering

system employing both numerals and letters. These two-number sets start with 00, 01, 02, 03, 04, $05,06,07,08,09,0 A, 0 B \ldots 0 Z$, followed by 10-1Z, 20-2Z, etc.

The CID Number appears on each page of the manuscript. The complete citation is used on the first page, and an abbreviated version on subsequent pages. 


\title{
Contents
}

\author{
vii Authors \\ ix Conference Committee
}

\section{KEYNOTE SESSION}

939403 Cognitive psychology meets art: exploring creativity, language, and emotion through live musical improvisation in film and theatre (Keynote Paper) [9394-40]

\section{SESSION 1 NEW FRONTIERS IN PERCEPTUAL IMAGE QUALITY: NEW TRENDS, EMERGING TECHNOLOGIES,} AND NOVEL EVALUATION TECHNIQUES

939405 Use of a local cone model to predict essential CSF light adaptation behavior used in the design of luminance quantization nonlinearities (Invited Paper) [9394-2]

939406 Display device-adapted video quality-of-experience assessment [9394-3]

939407 About subjective evaluation of adaptive video streaming (Invited Paper) [9394-4]

939408 A transformation-aware perceptual image metric [9394-5]

939409 Designing a biased specification-based subjective test of image quality (Invited Paper) [9394-6]

$93940 \mathrm{~A}$ Towards a comprehensive model for predicting the quality of individual visual experience [9394-7]

9394 OB Quality labeled faces in the wild (QLFW): a database for studying face recognition in realworld environments (Invited Paper) [9394-8]

9394 OC Parameterized framework for the analysis of visual quality assessments using crowdsourcing [9394-9]

9394 OD What do you think of my picture? Investigating factors of influence in profile images context perception (Invited Paper) [9394-10]

SESSION 2 PERCEPTION OF TEXTURE, GLOSS, AND COLOR IN MATERIALS: JOINT SESSION WITH CONFERENCES 9394 AND 9398

9394 OE Texture, illumination, and material perception [9394-11]

$9394 \mathrm{OF}$ Effects of contrast adjustment on visual gloss of natural textures [9394-12] 
9394 OG A subjective study and an objective metric to quantify the granularity level of textures [9394-13]

$9394 \mathrm{OH}$ Texture synthesis models and material perception in the visual periphery [9394-14]

KEYNOTE: JOINT SESSION WITH CONFERENCES 9394 AND 9395

9394 Ol Next gen perception and cognition: augmenting perception and enhancing cognition through mobile technologies [9394-57]

SESSION 3 NEW FRONTIERS IN PERCEPTUAL IMAGE QUALITY: NATURAL SCENES AND HIGHER-LEVEL STATISTICAL FEATURES

$93940 \mathrm{~J} \quad$ Feature maps driven no-reference image quality prediction of authentically distorted images (Invited Paper) [9394-15]

9394 OK Combining full-reference image visual quality metrics by neural network (Invited Paper) [9394-16]

$9394 \mathrm{OL}$ Geometrical and statistical properties of vision models obtained via maximum differentiation (Invited Paper) [9394-17]

9394 OM Relations between local and global perceptual image quality and visual masking (Invited Paper) [9394-18]

9394 ON Building structural similarity database for metric learning (Invited Paper) [9394-19]

\section{SESSION 4 LIGHTING, LIGHT, AND LIGHTNESS}

939400 Effect of daylight on atmosphere perception: comparison of a real space and visualizations (Invited Paper) [9394-20]

9394 OP The role of natural lighting diffuseness in human visual perception (Invited Paper) [9394-21]

$9394 \mathrm{OQ}$ The influence of lighting on visual perception of material qualities (Invited Paper) [9394-22]

9394 OR Effect of fixation positions on perception of lightness (Invited Paper) [9394-23]

SESSION 5 COLOR IN NEW TECHNOLOGIES FROM MOBILE TO CINEMA: JOINT SESSION WITH CONFERENCES 9394 AND 9395

9394 OT Reducing observer metamerism in wide-gamut multiprimary displays [9394-25]

9394 OU Gamut extension for cinema: psychophysical evaluation of the state of the art and a new algorithm [9394-26] 
$9394 \mathrm{OV} \quad$ Modeling the importance of faces in natural images [9394-27]

9394 OW Bridging the gap between eye tracking and crowdsourcing [9394-28]

9394 OX Visual saliency in MPEG-4 AVC video stream [9394-29]

9394 OY Learning visual balance from large-scale datasets of aesthetically highly rated images [9394-30]

$9394 \mathrm{OZ} \quad$ Assessing the influence of combinations of blockiness, blurriness, and packet loss impairments on visual attention deployment [9394-31]

SESSION 7 PERCEPTUAL DYNAMICS IN VISUALIZATION AND COMPUTER GRAPHICS

939410 Hue tinting for interactive data visualization [9394-32]

939411 On the visualization of tetrachromatic images [9394-33]

939412 Evaluating the perception of different matching strategies for time-coherent animations [9394-34]

939413 Perceptual evaluation of visual alerts in surveillance videos [9394-35]

SESSION 8 DIGITAL HUMANITIES: IMAGING, VISUALIZATION, AND ANALYTICS IN THE SOCIAL SCIENCES

939414 Examples of challenges and opportunities in visual analysis in the digital humanities (Invited Paper) [9394-36]

939417 Temporal evolution of brain reorganization under cross-modal training: insights into the functional architecture of encoding and retrieval networks [9394-56]

INTERACTIVE PAPER SESSION

939419 Do curved displays make for a more pleasant experience? [9394-41]

9394 1A The importance of accurate convergence in addressing stereoscopic visual fatigue [9394-42]

9394 1B Improvement in perception of image sharpness through the addition of noise and its relationship with memory texture [9394-43]

9394 1C Depth image enhancement using perceptual texture priors [9394-44]

9394 1D A patch-based cross masking model for natural images with detail loss and additive defects [9394-45] 
$9394 \mathrm{IE}$ Influence of high ambient illuminance and display luminance on readability and subjective preference [9394-46]

$9394 \mathrm{IF} \quad$ A no-reference bitstream-based perceptual model for video quality estimation of videos affected by coding artifacts and packet losses [9394-47]

9394 IG Saliency detection for videos using 3D FFT local spectra [9394-48]

$93941 \mathrm{H} \quad$ Perceived interest versus overt visual attention in image quality assessment [9394-49]

$939411 \quad$ A tone mapping operator based on neural and psychophysical models of visual perception [9394-50]

$93941 \mathrm{~J} \quad$ Illuminant color estimation based on pigmentation separation from human skin color [9394-51]

9394 IK Evaluation of color encodings for high dynamic range pixels [9394-52]

9394 IL Using false colors to protect visual privacy of sensitive content [9394-53]

$93941 \mathrm{M}$ The visual light field in paintings of Museum Prinsenhof: comparing settings in empty space and on objects [9394-54]

9394 iN Using V1-based models for difference perception and change detection [9394-55] 


\section{Authors}

Numbers in the index correspond to the last two digits of the six-digit citation identifier (CID) article numbering system used in Proceedings of SPIE. The first four digits reflect the volume number. Base 36 numbering is employed for the last two digits and indicates the order of articles within the volume. Numbers start with 00, 01, 02, 03, 04, 05, 06, 07, 08, 09, OA, OB...0Z, followed by 10-1Z, 20-2Z, etc.

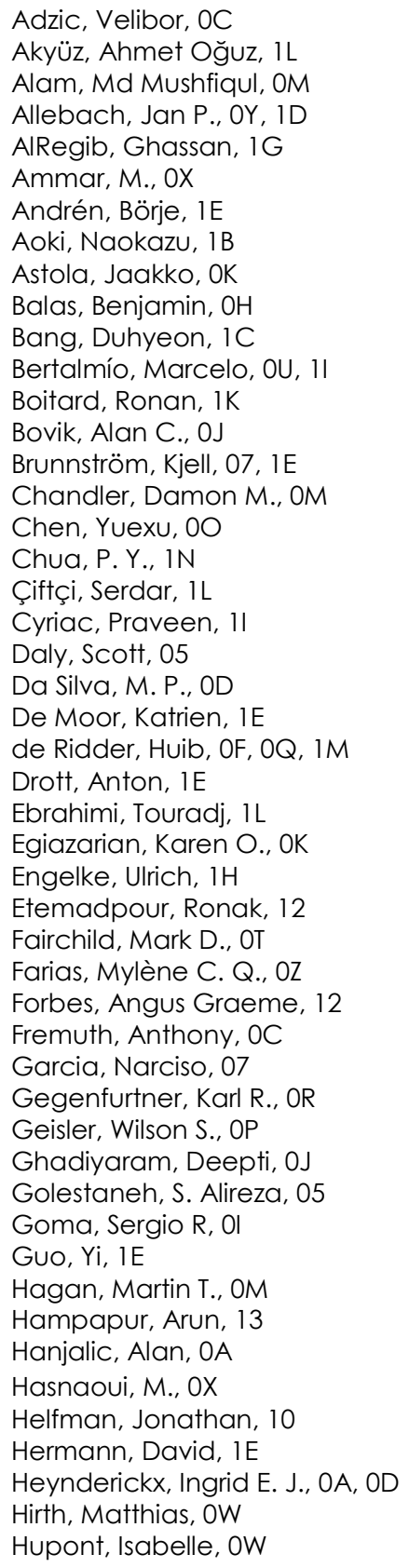

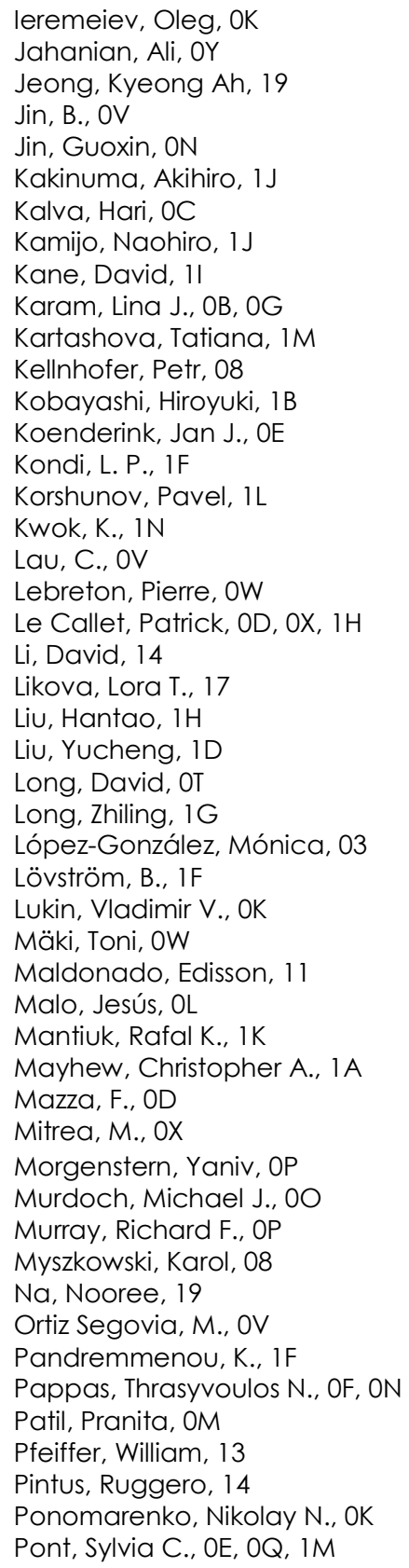


Pouli, Tania, $1 \mathrm{~K}$

Redi, Judith A., OA, $\mathrm{OZ}$

Rehman, Abdul, 06

Reibman, Amy R., 09

Restrepo, Alfredo, 11

Ritschel, Tobias, 08

Rogowitz, Bernice E., 13

Rushmeier, Holly, 14

Schoemaker, Marga, IM

Seidel, Hans-Peter, 08

Shahid, M., IF

Shaji, A., OV

Shim, Hyunjung, 1C

Silva, Alexandre F., $\mathrm{OZ}$

Simoncelli, Eero P., OL

Skodras, Evangelos, OW

Stokkermans, Mariska G. M., 00

Subedar, Mahesh M., OG

Suk, Hyeon-Jeong, 19

Süsstrunk, S., OV

Takahashi, Hiroshi, 1J

Tanaka, Satomi, $1 \mathrm{~J}$

Tavakoli, Samira, 07

te Pas, Susan F., $1 \mathrm{M}$

Topkara, Mercan, 13

Toscani, Matteo, OR

Tsumura, Norimichi, $1 \mathrm{~J}$

Valsecchi, Matteo, OR

van Doorn, Andrea J., OE

Vazquez-Corral, Javier, OU, 11

Villegas, Javier, 12

Vishwanathan, S.V.N., OY

Vogels, Ingrid M. C. L., 00

Wan, Xiazi, 1B

Wang, Jing, OF

Wang, Kun, $1 \mathrm{E}$

Wang, Zhou, 06

Wijntjes, Maarten W. A., OE

Wong, Christiana, 14

Yang, Ying, 14

Yildirim, G., OV

Zamir, Syed Waqas, OU

Zeng, Kai, 06

Zhang, Fan, $0 Q$

Zhang, Wei, $1 \mathrm{H}$

Zhu, Tong, OB

Zhu, Yi, OA 


\section{Conference Committee}

Symposium Chair

Sheila S. Hemami, Northeastern University (United States)

Symposium Co-chair

Choon-Woo Kim, Inha University (Korea, Republic of)

Conference Chairs

Bernice E. Rogowitz, Visual Perspectives Research and Consulting (United States)

Thrasyvoulos N. Pappas, Northwestern University (United States)

Huib de Ridder, Technische Universiteit Delft (Netherlands)

Conference Program Committee

Albert J. Ahumada Jr., NASA Ames Research Center (United States) Jan P. Allebach, Purdue University (United States)

Erhardt Barth, Universität zu Lübeck (Germany)

Walter R. Bender, Sugar Labs (United States)

Michael H. Brill, Datacolor (United States)

Damon M. Chandler, Oklahoma State University (United States)

John C. Dalton, Synthetik Software (United States)

Scott J. Daly, Dolby Labatories, Inc. (United States)

Ulrich Engelke, Commonwealth Scientific and Industrial Research Organisation (Australia)

Elena A. Fedorovskaya, Rochester Institute of Technology

(United States)

James A. Ferwerda, Rochester Institute of Technology (United States)

Jennifer L. Gille, Qualcomm Technologies Inc. (United States)

Sergio R. Goma, Qualcomm Inc. (United States)

Sheila S. Hemami, Northeastern University (United States)

Hari Kalva, Florida Atlantic University (United States)

Stanley A. Klein, University of California, Berkeley (United States)

Patrick Le Callet, Université de Nantes (France)

Lora T. Likova, The Smith-Kettlewell Eye Research Institute (United States)

John J. McCann, McCann Imaging (United States)

Jeffrey B. Mulligan, NASA Ames Research Center (United States)

Karol Myszkowski, Max-Planck-Institut für Informatik (Germany)

Adar Pelah, The University of York (United Kingdom)

Eliezer Peli, Schepens Eye Research Institute (United States) 
Judith A. Redi, Technische Universiteit Delft (Netherlands)

Hawley K. Rising III, Consultant (United States)

Sabine Süsstrunk, École Polyłechnique Fédérale de Lausanne

(Switzerland)

Christopher W. Tyler, The Smith-Kettlewell Eye Research Institute

(United States)

Andrew B. Watson, NASA Ames Research Center (United States)

Michael A. Webster, University of Nevada, Reno (United States)

\section{Session Chairs}

Keynote Session

Bernice E. Rogowitz, Visual Perspectives Research and Consulting (United States)

Thrasyvoulos N. Pappas, Northwestern University (United States)

Huib de Ridder, Technische Universiteit Delft (Netherlands)

1 New Frontiers in Perceptual Image Quality: New Trends, Emerging Technologies, and Novel Evaluation Techniques

Damon M. Chandler, Oklahoma State University (United States)

Huib de Ridder, Technische Universitet Delft (Netherlands)

2 Perception of Texture, Gloss, and Color in Materials: Joint Session with Conferences 9394 and 9398

Bernice E. Rogowitz, Visual Perspectives Research and Consulting (United States)

Maria Valezzka Ortiz Segovia, Océ Print Logic Technologies (France)

Andreas Hoepe, Physikalisch-Technische Bundesanstalt (Germany)

Posters Fast Forward

Patrick Le Callet, Université de Nantes (France)

3 New Frontiers in Perceptual Image Quality: Natural Scenes and Higher-Level Statistical Features

Damon M. Chandler, Oklahoma State University (United States)

4 Lighting, Light, and Lightness

Sylvia C. Pont, Technische Universiteit Delft (Netherlands)

Keynote: Joint Session with Conferences 9394 and 9395

John J. McCann, McCann Imaging (United States)

Bernice E. Rogowitz, Visual Perspectives Research and Consulting (United States)

5 Color in New Technologies from Mobile to Cinema: Joint Session with Conferences 9394 and 9395

John J. McCann, McCann Imaging (United States) 
6 Attention and Visual Saliency

Huib de Ridder, Technische Universiteit Delft (Netherlands)

7 Perceptual Dynamics in Visualization and Computer Graphics

Bernice E. Rogowitz, Visual Perspectives Research and Consulting (United States)

8 Digital Humanities: Imaging, Visualization, and Analytics in the Social Sciences

Bernice E. Rogowitz, Visual Perspectives Research and Consulting (United States) 
Prof. of SPIE-IS\&T Vol. $9394939401-12$

Downloaded From: https://www.spiedigitallibrary.org/conference-proceedings-of-spie on 26 Apr 2023 Terms of Use: https://www.spiedigitallibrary.org/terms-of-use 